\title{
Analysis of Green Living Walls: Individual Awareness about its Functional Value and Aesthetical Quality
}

\author{
Sadia Farooq ${ }^{1}$, Mohammad Arif Kamal ${ }^{2, *}$ \\ ${ }^{1}$ Department of Family and Consumer Sciences, University of Home Economics, Lahore, Pakistan \\ ${ }^{2}$ Architecture Section, Aligarh Muslim University, Aligarh-202002, India
}

Received May 12, 2020; Revised June 9, 2020; Accepted July 20, 2020

Copyright $@ 2020$ by authors, all rights reserved. Authors agree that this article remains permanently open access under the terms of the Creative Commons Attribution License 4.0 International License

\begin{abstract}
The need to build Green Living Walls (GLWs) has multipurpose functions. It can save space since it is built vertically, can improve air quality due to its vegetation style, reduces temperature into the interior and exterior of the building and also reduces the noise pollution. This research is conducted to document the awareness level of individuals in Pakistan, which will help in making strategies for the future about Green Living Walls. This documentation can also help in comparing the awareness level of individuals regarding the aesthetics and functionality of GLW. A sample of 100 individuals has been selected for the survey. The analysis has been done on Statistical package for the Social Sciences (SPSS) software, and the results have been analyzed on the basis of percentage, frequencies, and chi-square test to compare the relationship of different statements. Most of the individuals answered that they were familiar with the GLWs and would also like to install GLWs at homes, few individuals rejected the idea of GLWs. Individuals also agreed that GLWs help in reducing the noise level, improving the air quality, enhancing the aesthetical value, shading and increasing the energy level. The results of Chi-Square have also shown that GLWs enhances air quality, boost energy levels, and also helps in reducing noise and temperature. Many individuals preferred GLWs and considered it beneficial for the home environment, even if it has a little harmful effect, because sometimes it also attracted insects and mosquitoes.
\end{abstract}

Keywords Green Living Wall, Benefits, Functionality, Aesthetics

\section{Introduction}

The globalization has given a chance to experiment openly to improve the environment in the buildings by implementing various sustainable design methodologies, such as Green Living Walls (GLWs) [1]. And people have also realized the importance of GLWs in urban areas when everybody does not have time to go to the parks [2]. The situation raised the worth of today's research to enjoy the home greenery and vegetation. The research on the awareness level about GLW is also validated, since the GLW is installed vertically and can be made in small apartments and on busy roads [3]. The GLWs enhances the surrounding environmental quality and reduces the negative impacts of buildings on humans. It is an approach to realize the concept of sustainable cities; This can be a joint venture between the benefits of plants and building structures to retrofit the cities with minimized pollutants $[2,4,5,6,7]$. The concept of bio-philic design is giving rise to accommodate natural elements into man-made structures and surroundings. The idea is that individuals should feel better and work close to nature. A very basic benefit of plants is provision of fresh oxygenated air and exhaust of carbon dioxide from the surroundings [8].

The GLW brings nature close to us. The strength can vary for both walls, as the living wall cannot be very strong as compared to the actual concrete wall. The Living walls can be built upon the frame or skeleton which is filled with greenery, planters, leaves and flowers. The advancement also provides the self-watering mechanism to automatically water the plants, which is better than the conventional method of manual watering $[9,10]$. There is another benefit of space utilization, since the living wall occupies a very small amount of space and its extension is vertical. A garden, field, or park requires a large space but in Green Living Wall, numerous plants can be joined together into a small area. By using the GLW, the plants provide the maximum benefit without occupying the floor space [11].

The living walls can also grow in all types of weather because of a variety of plants available in the local nurseries, so that everyone can select from watery plants to 
the cactus species which need minimum water [12]. The basic operational requirement is to regularly maintain the GLW such as its watering, clipping, nutrients, fertilizers, etc., because if left unobserved or ignored, the living wall or the plants on it will be damaged [9]. The living wall is not only the breathing wall, providing oxygenated fresh air but it can also act as a noise reduction wall for minimizing the level of unwanted sounds coming from the surrounding environment [11]. Many researchers have also proved that there is a decrease in hourly temperature not only inside the building but also outside the building, and even the ambient and humidity got better with the use of GLW. This also impacts on energy usage in the buildings [13]. The experts are working on GLW to make living walls more sustainable in terms of design, construction, and maintenance. Some researchers have also showed that some important aspects should be considered while making standards for GLW. The main consideration can be the performance of the living wall after maturation. The idea is to develop sets of standards for off-site and on-site production of Green Living walls and also its lifetime and environmental focus [2].

The researches approached that the living walls are not fully accepted in the cities and their environmental quality restoration is not recognized in the majority of the population. The reasons may be due to the lack of awareness and data of the benefits related to sustainable environment. Therefore, we can highlight the economic benefits of GLW through the thermal performance of the building and the reduced use of energy. The living wall can be built upon a simple climbing plant or a designed living wall. The overall performance can be the same for both the conditions, since both provides vertical scale and uses less horizontal space, is eco-friendly, helps in noise reduction, is economical and has thermal benefits, aesthetics, and acts as an envelope for the building $[7,13,15]$.

The focus is on sustainable construction which needs a lot of ways to discover, one of which is to construct green or green $[6,11,15]$ which can be achieved through GLW. The Living wall is not a new phenomenon, it has been used for centuries, adjusted in the buildings to provide shades and lower the temperature. The GLW was being used for protection from the fast wind pressure. It was also used for the growing of vegetables. The prominent example is the hanging garden of Babylon which was included in seven wonders of the world. This was an original example of a living wall between 600 to 800 BC $[11,16]$.

The human health is very important, and for having good air quality for pure breathing can be fulfilled by GLW $[4,17,18]$. However, the living walls are not famous especially in common individuals, specifically in Pakistan. The reason can be the lack of awareness about living wall benefits. The gap can be filled by first to estimate the awareness level of individuals about the functionality and aesthetics of GLW. The purpose of this paper is also to examine the awareness about the functionality and aesthetics of a GLW in individuals. The acceptance of environmental and energy efficiency measures by the individual of Pakistan is slow and new ideas are being accepted here with time.

\section{Research Methodology}

The research methodology approached quantitative survey analysis method to gather data about individual awareness regarding GLWs in urban areas. The study was conducted to find out the individuals' awareness level regarding the benefits; functionality and aesthetical impact on humans, when there are buildings in the surroundings such as in neighboring houses and societies. The questionnaire covered two essential features, first one to find the awareness about the functionality of the GLW and secondly about the aesthetic appeal of GLW among individuals. The GLWs built in the city were notified to the audience, wherever possible, such as if a person is having a GLW near his residence or has experienced it in any other place. Individuals were asked to fill the questionnaire. The questionnaire consists of four demographical features such as name, age, qualification and gender. The other statements were in the form of questions and a total of fourteen statements were made to find out awareness or familiarity level of individuals about GLW, its functionality and aesthetics. Of all the statements, one statement was about the awareness and familiarity about GLW, nine statements were asked about the awareness of functionality of GLWs and the remaining four statements were about the awareness of the aesthetic quality of GLWs.

The data was collected in February 2020, to document and create awareness among individuals about the importance and benefits of GLW through this paper. The questionnaires were filled by 100 individuals randomly from different localities of Lahore in Pakistan. The individuals were contacted with a reference like friends or family friends and asked their willingness to fill the questionnaire. The random sampling techniques were used to fulfill the objective that the study wants to collect information about individuals' awareness levels of GLWs. The Chi-Square method is also used to compare the GLWs' performance of air quality as well as to boost energy level which helps reducing noise and temperature.

\section{Data Analysis}

The analysis was concluded on Statistical package for the Social Sciences (SPSS) software and results are shown in frequencies and percentages, and then the Chi-Square test was applied to find out the association between different statements and individual responses about their familiarity with GLW, its functional characteristics and aesthetics. 
Table 1. Familiarity of Individuals with Green Living Wall (GLW)

\begin{tabular}{|c|c|c|c|c|}
\hline Options & Frequency & Percent & $\begin{array}{c}\text { Valid } \\
\text { Percent }\end{array}$ & $\begin{array}{c}\text { Cumulative } \\
\text { Percent }\end{array}$ \\
\hline Not at all & 3 & 3.0 & 3.0 & 3.0 \\
\hline No & 10 & 10.0 & 10.0 & 13.0 \\
\hline $\begin{array}{c}\text { To some } \\
\text { extent }\end{array}$ & 11 & 11.0 & 11.0 & 24.0 \\
\hline May be & 13 & 13.0 & 13.0 & 37.0 \\
\hline Yes & 63 & 63.0 & 63.0 & 100.0 \\
\hline Total & 100 & 100 & 100 & \\
\hline
\end{tabular}

Table 1 concludes that $63 \%$ of individuals were familiar with GLW. 10\% individuals were not familiar with GLW and $13 \%$ individual gave their answer as maybe, $11 \%$ individual gave their answer as to some extent and 3\% of the individual gave their answer as not at all. A maximum number of individuals said that they were familiar with the GLW. The individual was briefed about GLW before filling the rest of the questionnaire. When they asked to observe around in their city, they recalled the built-up GLWs around them.

Table 2. Awareness about shade provided by GLW in summer

\begin{tabular}{|c|c|c|c|c|}
\hline Options & Frequency & Percent & $\begin{array}{c}\text { Valid } \\
\text { Percent }\end{array}$ & $\begin{array}{c}\text { Cumulative } \\
\text { Percent }\end{array}$ \\
\hline Not at all & 2 & 2.0 & 2.0 & 2.0 \\
\hline No & 6 & 6.0 & 6.0 & 8.0 \\
\hline $\begin{array}{c}\text { To some } \\
\text { extent }\end{array}$ & 9 & 9.0 & 9.0 & 17.0 \\
\hline May be & 29 & 29.0 & 29.0 & 46.0 \\
\hline Yes & 54 & 54.0 & 54.0 & 100.0 \\
\hline Total & 100 & 100 & 100 & \\
\hline
\end{tabular}

Table 2 concludes that $54 \%$ individual said that they are aware that GLWs provides shade in summer. 29\% individual gave their answer as may be, 9\% answered to some extent, $6 \%$ answered no and only $2 \%$ answered not at all. A maximum number of individuals said that GLWs provide shade in summer.

Table 3. Air quality enhancement by Green Living Wall

\begin{tabular}{|c|c|c|c|c|}
\hline Options & Frequency & Percent & $\begin{array}{c}\text { Valid } \\
\text { Percent }\end{array}$ & $\begin{array}{c}\text { Cumulative } \\
\text { Percent }\end{array}$ \\
\hline Not at all & 1 & 1.0 & 1.0 & 1.0 \\
\hline No & 7 & 7.0 & 7.0 & 8.0 \\
\hline $\begin{array}{c}\text { To some } \\
\text { extent }\end{array}$ & 8 & 8.0 & 8.0 & 16.0 \\
\hline May be & 16 & 16.0 & 16.0 & 32.0 \\
\hline Yes & 68 & 68.0 & 68.0 & 100.0 \\
\hline Total & 100 & 100 & 100 & \\
\hline
\end{tabular}

Table 3 concludes that $68 \%$ individual answered that they know that GLWs enhance air quality. $16 \%$ answered maybe, $8 \%$ answered to some extent, $7 \%$ answered no and only $1 \%$ answered not at all. A maximum number of individuals said that green living walls enhance air quality.
Table 4. GLW's help to reduce noise pollution

\begin{tabular}{|c|c|c|c|c|}
\hline Options & Frequency & Percent & $\begin{array}{c}\text { Valid } \\
\text { Percent }\end{array}$ & $\begin{array}{c}\text { Cumulative } \\
\text { Percent }\end{array}$ \\
\hline Not at all & 5 & 5.0 & 5.0 & 5.0 \\
\hline No & 15 & 15.0 & 15.0 & 20.0 \\
\hline $\begin{array}{c}\text { To some } \\
\text { extent }\end{array}$ & 7 & 7.0 & 7.0 & 27.0 \\
\hline May be & 36 & 36.0 & 36.0 & 63.0 \\
\hline Yes & 37 & 37.0 & 37.0 & 100.0 \\
\hline Total & 100 & 100 & 100 & \\
\hline
\end{tabular}

Table 4 concludes that $37 \%$ of individuals answered yes when asked about the GLWs help to reduce noise pollution. $36 \%$ answered maybe, $15 \%$ answered no, and $7 \%$ and 5\% answered respectively to some extent and not at all. The majority of individuals answered that GLWs help in noise reduction.

Table 5. GLW's help to reduce temperature

\begin{tabular}{|c|c|c|c|c|}
\hline Options & Frequency & Percent & $\begin{array}{c}\text { Valid } \\
\text { Percent }\end{array}$ & $\begin{array}{c}\text { Cumulative } \\
\text { Percent }\end{array}$ \\
\hline Not at all & 1 & 1.0 & 1.0 & 1.0 \\
\hline No & 2 & 2.0 & 2.0 & 3.0 \\
\hline $\begin{array}{c}\text { To some } \\
\text { extent }\end{array}$ & 9 & 9.0 & 9.0 & 12.0 \\
\hline May be & 16 & 16.0 & 16.0 & 28.0 \\
\hline Yes & 72 & 72.0 & 72.0 & 100.0 \\
\hline Total & 100 & 100 & 100 & \\
\hline
\end{tabular}

Table 5 concludes that $72 \%$ of individuals answered yes when they were asked about the GLWs help to reduce the temperature in the surroundings. 16\% answered maybe, $9 \%$ answered to some extent and only $2 \%$ and $1 \%$ answered respectively no and not at all. The majority of individuals agreed that GLWs help in the reduction of temperature in the surroundings.

Table 6. GLW's are beneficial for home environment

\begin{tabular}{|c|c|c|c|c|}
\hline Options & Frequency & Percent & $\begin{array}{c}\text { Valid } \\
\text { Percent }\end{array}$ & $\begin{array}{c}\text { Cumulativ } \\
\text { e Percent }\end{array}$ \\
\hline No & 5 & 5.0 & 5.0 & 5.0 \\
\hline $\begin{array}{c}\text { To some } \\
\text { extent }\end{array}$ & 12 & 12.0 & 12.0 & 17.0 \\
\hline May be & 23 & 23.0 & 23.0 & 40.0 \\
\hline Yes & 60 & 60.0 & 60.0 & 100.0 \\
\hline Total & 100 & 100 & 100 & \\
\hline
\end{tabular}

Table 6 concludes that $60 \%$ of individuals considered GLWs beneficial for the home environment, 23\% of individuals answered maybe and respectively $12 \%$ and $5 \%$ answered to some extent and no. The majority of individuals agreed that GLWs is beneficial for the home environment.

Table 7 concludes that $52 \%$ of individuals answered that they will have GLWs in vertical arrangement because it occupy less space, 26\% answered maybe and 11\%, 11\% 
answered respectively to some extent and no. The majority of individuals were willing to have GLW in a vertical arrangement as it occupies less space.

Table 7. Willingness to occupy GLW in vertical arrangement since it occupies less space at home

\begin{tabular}{|c|c|c|c|c|}
\hline Options & Frequency & Percent & $\begin{array}{c}\text { Valid } \\
\text { Percent }\end{array}$ & $\begin{array}{c}\text { Cumulative } \\
\text { Percent }\end{array}$ \\
\hline No & 11 & 11.0 & 11.0 & 11.0 \\
\hline $\begin{array}{c}\text { To some } \\
\text { extent }\end{array}$ & 11 & 11.0 & 11.0 & 22.0 \\
\hline May be & 26 & 26.0 & 26.0 & 48.0 \\
\hline Yes & 52 & 52.0 & 52.0 & 100.0 \\
\hline Total & 100 & 100 & 100 & \\
\hline
\end{tabular}

Table 8. GLW's has more harmful impact than its benefits

\begin{tabular}{|c|c|c|c|c|}
\hline Options & Frequency & Percent & $\begin{array}{c}\text { Valid } \\
\text { Percent }\end{array}$ & $\begin{array}{c}\text { Cumulative } \\
\text { Percent }\end{array}$ \\
\hline Not at all & 9 & 9.0 & 9.0 & 9.0 \\
\hline No & 53 & 53.0 & 53.0 & 62.0 \\
\hline $\begin{array}{c}\text { To some } \\
\text { extent }\end{array}$ & 8 & 8.0 & 8.0 & 70.0 \\
\hline May be & 25 & 25.0 & 25.0 & 95.0 \\
\hline Yes & 5 & 5.0 & 5.0 & 100.0 \\
\hline Total & 100 & 100 & 100 & \\
\hline
\end{tabular}

Table 8 concludes that $53 \%$ of individuals answered no when asked about the GLWs have more harmful impacts than its benefits. 25\% answered maybe, 9\% answered not at all, $8 \%$ answered to some extent and only 5\% answered yes. The majority of individuals agreed that GLWs are more beneficial than harmful.

Table 9. GLW's attract insects, but still want it at home

\begin{tabular}{|c|c|c|c|c|}
\hline Options & Frequency & Percent & $\begin{array}{c}\text { Valid } \\
\text { Percent }\end{array}$ & $\begin{array}{c}\text { Cumulative } \\
\text { Percent }\end{array}$ \\
\hline Not at all & 4 & 4.0 & 4.0 & 4.0 \\
\hline No & 20 & 20.0 & 20.0 & 24.0 \\
\hline $\begin{array}{c}\text { To some } \\
\text { extent }\end{array}$ & 20 & 20.0 & 20.0 & 44.0 \\
\hline May be & 32 & 32.0 & 32.0 & 76.0 \\
\hline Yes & 24 & 24.0 & 24.0 & 100.0 \\
\hline Total & 100 & 100 & 100 & \\
\hline
\end{tabular}

Table 9 concludes that $32 \%$ individuals answered that due to having insects in GLWs they may be interested to have it at their homes, 24\% answered yes, 20\% answered in negative and next 20\% answered to some extent and only $4 \%$ were not willing to have GLWs because of insects.

Table 10 concludes that $67 \%$ individuals gave their answer as yes when asked to give preference for GLWs in residential areas, 10\% individual answered in negative, 14\% individuals answered may be, $8 \%$ individuals answered to some extent and $1 \%$ individuals answered not at all. The maximum number of individuals said that they preferred
GLWs in residential area.

Table 10. Preference for GLWs in residential area due to its functionality

\begin{tabular}{|c|c|c|c|c|}
\hline Options & Frequency & Percent & $\begin{array}{c}\text { Valid } \\
\text { Percent }\end{array}$ & $\begin{array}{c}\text { Cumulative } \\
\text { Percent }\end{array}$ \\
\hline Not at all & 1 & 1.0 & 1.0 & 1.0 \\
\hline No & 10 & 10.0 & 10.0 & 11.0 \\
\hline $\begin{array}{c}\text { To some } \\
\text { extent }\end{array}$ & 8 & 8.0 & 8.0 & 19.0 \\
\hline May be & 14 & 14.0 & 14.0 & 33.0 \\
\hline Yes & 67 & 67.0 & 67.0 & 100.0 \\
\hline Total & 100 & 100 & 100 & \\
\hline
\end{tabular}

Table 11. GLWs boost up energy level due to its aesthetical impact

\begin{tabular}{|c|c|c|c|c|}
\hline Options & Frequency & Percent & $\begin{array}{c}\text { Valid } \\
\text { Percent }\end{array}$ & $\begin{array}{c}\text { Cumulative } \\
\text { Percent }\end{array}$ \\
\hline No & 7 & 7.0 & 7.0 & 7.0 \\
\hline $\begin{array}{c}\text { To some } \\
\text { extent }\end{array}$ & 16 & 16.0 & 16.0 & 23.0 \\
\hline May be & 21 & 21.0 & 21.0 & 44.0 \\
\hline Yes & 56 & 56.0 & 56.0 & 100.0 \\
\hline Total & 100 & 100 & 100 & \\
\hline
\end{tabular}

Table 11 concludes that 56\% answered yes when asked about the GLWs boost up energy level in individuals like greenery, 21\% individuals answered may be, $16 \%$ individuals answered to some extent, $7 \%$ individuals answered no. The maximum number of individuals answered that GLW boost up energy level like greenery.

Table 12. GLWs pleasant impact on individuals

\begin{tabular}{|c|c|c|c|c|}
\hline Options & Frequency & Percent & $\begin{array}{c}\text { Valid } \\
\text { Percent }\end{array}$ & $\begin{array}{c}\text { Cumulative } \\
\text { Percent }\end{array}$ \\
\hline No & 3 & 3.0 & 3.0 & 3.0 \\
\hline $\begin{array}{c}\text { To some } \\
\text { extent }\end{array}$ & 6 & 6.0 & 6.0 & 9.0 \\
\hline May be & 13 & 13.0 & 13.0 & 22.0 \\
\hline Yes & 78 & 78.0 & 78.0 & 100.0 \\
\hline Total & 100 & 100 & 100 & \\
\hline
\end{tabular}

Table 12 concludes that $78 \%$ individuals answered yes about the pleasant impact of GLWs on them, $13 \%$ of the individuals gave their answer as may be, $6 \%$ of the individuals gave their answer to some extent and only $3 \%$ answered no. The maximum number of individuals said that GLWs have a pleasant impact on them.

Table 13 concludes that $76 \%$ individuals gave their answer in affirmation, when asked about the GLWs boost up their mood because of its beauty, $13 \%$ answered maybe, $6 \%$ answered to some extent and only 5\% answered no. The majority of individuals agreed that GLWs boost up mood because of its beauty. 
Table 13. GLWs boost up mood because of its beauty

\begin{tabular}{|c|c|c|c|c|}
\hline Options & Frequency & Percent & $\begin{array}{c}\text { Valid } \\
\text { Percent }\end{array}$ & $\begin{array}{c}\text { Cumulative } \\
\text { Percent }\end{array}$ \\
\hline No & 3 & 3.0 & 3.0 & 3.0 \\
\hline $\begin{array}{c}\text { To some } \\
\text { extent }\end{array}$ & 6 & 6.0 & 6.0 & 9.0 \\
\hline May be & 13 & 13.0 & 13.0 & 22.0 \\
\hline Yes & 78 & 78.0 & 78.0 & 100.0 \\
\hline Total & 100 & 100 & 100 & \\
\hline
\end{tabular}

Table 14. Willingness to have GLWs at home due to its aesthetics

\begin{tabular}{|c|c|c|c|c|}
\hline Options & Frequency & Percent & $\begin{array}{c}\text { Valid } \\
\text { Percent }\end{array}$ & $\begin{array}{c}\text { Cumulative } \\
\text { Percent }\end{array}$ \\
\hline Not at all & 3 & 3.0 & 3.0 & 3.0 \\
\hline No & 8 & 8.0 & 8.0 & 11.0 \\
\hline $\begin{array}{c}\text { To some } \\
\text { extent }\end{array}$ & 7 & 7.0 & 7.0 & 18.0 \\
\hline May be & 24 & 24.0 & 24.0 & 42.0 \\
\hline Yes & 58 & 58.0 & 58.0 & 100.0 \\
\hline Total & 100 & 100 & 100 & \\
\hline
\end{tabular}

Table 14 shows $58 \%$ individuals were willing to have GLWs, 24\% answered may be, 8\%, 7\% and 3\% answered no, to some extent and not at all respectively. Majority of individuals agreed to have GLWs at their homes.

Table 15. Comparison between GLWs function to enhance air quality and boosting energy level due to its aesthetic quality

\begin{tabular}{|c|c|c|c|}
\hline \multicolumn{5}{|c|}{ Chi-Square Tests } \\
\hline & Value & Df & $\begin{array}{c}\text { Asymptotic } \\
\text { Significance } \\
(2-\text {-sided })\end{array}$ \\
\hline Pearson Chi-Square & $127.229^{\mathrm{a}}$ & 12 & .000 \\
\hline Likelihood Ratio & 124.753 & 12 & .000 \\
\hline $\begin{array}{c}\text { Linear-by-Linear } \\
\text { Association }\end{array}$ & 19.648 & 1 & .000 \\
\hline N of Valid Cases & 100 & & \\
\hline $\begin{array}{l}16 \text { cells (80.0\%) have expected count less than 5. The minimum } \\
\text { expected count is .07 }\end{array}$
\end{tabular}

Table 15 shows that individuals agreed that GLWs enhances air quality and boost energy level due to the aesthetic quality. The calculated value doesn't lie in the critical region so relationship is strong between these two statements.

Table 16. Comparison between GLWs to reduce noise \& temperature

\begin{tabular}{|c|c|c|c|}
\hline \multicolumn{5}{|c|}{ Chi-Square Tests } \\
\hline Options & Value & Df & $\begin{array}{c}\text { Asymptotic } \\
\text { Significance } \\
(2-\text {-sided })\end{array}$ \\
\hline Chi-Square & $126.047^{\mathrm{a}}$ & 16 & .000 \\
\hline Likelihood Ratio & 99.251 & 16 & .000 \\
\hline $\begin{array}{c}\text { Linear-by-Linear } \\
\text { Association }\end{array}$ & 17.351 & 1 & .000 \\
\hline N of Valid Cases & 100 & & \\
\hline $\begin{array}{c}19 \text { cells (76.0\%) have expected count less than 5. The minimum } \\
\text { expected count is .05 }\end{array}$
\end{tabular}

Table 16 concludes that individuals agreed that GLWs help in reducing noise and temperature. The calculated value doesn't lie in the critical region so the correlation is present between these two factors.

Table 17. Comparison between GLWs preference in residential area and beneficial for home environment

\begin{tabular}{|c|c|c|c|}
\hline \multicolumn{5}{|c|}{ Chi-Square Tests } \\
\hline & Value & Df & $\begin{array}{c}\text { Asymptotic } \\
\text { Significance } \\
\text { (2-sided) }\end{array}$ \\
\hline Pearson Chi-Square & $158.688^{\mathrm{a}}$ & 12 & .000 \\
\hline Likelihood Ratio & 141.959 & 12 & .000 \\
\hline $\begin{array}{c}\text { Linear-by-Linear } \\
\text { Association }\end{array}$ & 25.740 & 1 & .000 \\
\hline N of Valid Cases & 100 & & \\
\hline $\begin{array}{l}15 \text { cells (75.0\%) have expected count less than 5. The minimum } \\
\text { expected count is .05 }\end{array}$ \\
\hline
\end{tabular}

Table 17 concludes that individuals agreed that they prefer GLWs in residential areas and they are beneficial for home environment. The calculated value doesn't lie in the critical region so the correlation is present between these two factors.

Table 18. Comparison between GLWs harmful effect, attract insects, but individuals still want to install it

\begin{tabular}{|c|c|c|c|}
\hline \multicolumn{4}{|c|}{ Chi-Square Tests } \\
\hline & Value & Df & $\begin{array}{c}\text { Asymptotic } \\
\text { Significance (2-sided) }\end{array}$ \\
\hline $\begin{array}{c}\text { Pearson } \\
\text { Chi-Square }\end{array}$ & $176.874^{\mathrm{a}}$ & 12 & .000 \\
\hline Likelihood Ratio & 171.977 & 12 & .000 \\
\hline $\begin{array}{c}\text { Linear-by-Linear } \\
\text { Association }\end{array}$ & 27.521 & 1 & .000 \\
\hline N of Valid Cases & 100 & & \\
\hline $\begin{array}{c}\text { 16 cells (80.0\%) have expected count less than 5. The minimum } \\
\text { expected count is 0.14 }\end{array}$ &
\end{tabular}

Table 18 concludes that individuals agreed that they preferred GLWs even if it has a harmful effect and attracts insects; they also wanted to install it. The calculated value doesn't lie in the critical region so the correlation is present between these two factors.

\section{Research Summary and Discussion}

This research was conducted about the contribution of GLW to the environment and the beauty of the space. The benefits, function, and aesthetic were discussed in this research. A questionnaire was prepared for quantitative research conducted on 100 individuals. After collecting data, all the data was analyzed by a statistical approach to generate a solid analysis. Demographic information, frequencies of responses towards every question and comparison of different responses were performed by SPSS (Statistical Package of Social Sciences). In 
conclusion, statistics show that more than $70 \%$ agreed on the need for GLWs and they think GLWs reduces the temperature and enhances the air quality [6,11,13,15.17]. More than $60 \%$ of visitors think that it enhances the energy level at work and they want GLWs in their living areas and work areas. They said they feel good to see these Green living walls around. According to the arrangement of the GLWs, more than $40 \%$ of individuals were willing for it because of vertical arrangement [3, 11,18]. GLWs attract insects but still around $30 \%$ of visitors want to install these walls at their homes [4,5].

The visitors gave a huge response in favor of GLWs and statistics show that they need it in their homes. More work is required to bring awareness about GLWs in society and need to set the trend for the betterment of the environment and health. It was found that GLWs affect individuals in many different ways. Most visitors found the GLWs very pleasing, enhancing, refreshing and important for society [13]. GLWs help in reducing noise along with temperature $[11,13,15]$. The results of Chi-Square also conclude that GLWs perform both tasks i.e. enhancing the air quality as its functional aspect as well as boosting the energy levels because of its aesthetical quality $[11,17,18]$. The individuals preferred GLWs in residential areas and consider it beneficial for the home environment. They also preferred GLWs even if it has a harmful effect and attracts insects. Hence, the research is very helpful that people can build up their own GLWs in even small areas and can enjoy the benefits of it functional value and aesthetical quality [2]. GLWs can be an effort to develop cities more sustainable than now and can convert human energy busy with nature, especially in urban areas [4,5]. The importance of GLWs cannot be denied because of their positive impact on human health and in reducing pollution.

\section{REFERENCES}

[1] H. G. Kim, S. S. Kim. Occupants Awareness of and Satisfaction with Green Building Technologies in a Certified Office Building. Sustainability, Vol. 12, No. 5, 2109, 2020.

[2] X. Zhang, Z. Ni, Y. Wang, S. Chen, \& B. Xia. Public perception and preferences of small urban green infrastructures: A case study in Guangzhou, China. Urban Forestry \& Urban Greening, 126700, 2020.

[3] A. Romanova G. Salah. Social study on public awareness of the Living Green Wall health benefits, 2018.

[4] X. Xu, J. Xia, Y. Gao, \& W. Zheng. Additional focus on particulate matter wash-off events from leaves is required: A review of studies of urban plants used to reduce airborne particulate matter pollution. Urban Forestry \& Urban Greening, 48, 126559, 2020.

[5] M. Manso, J. Castro-Gomes. Green wall systems: A review of their characteristics. Renewable and Sustainable Energy Reviews, Vol. 41, 863-871, 2015.

[6] S. Farooq, I. Yaqoob. Awareness towards Efficiency of Green and Conventional Building Materials used in Pakistan. Pakistan Academy of Sciences A. Physical and Computational Sciences 56 (3): 59-68. ISSN: 2518-4245 (print), 2518-4253 (online), 2019.

[7] H. S. Fowdar, A. Deletic, B. E. Hatt, P. L. Cook. Nitrogen removal in greywater living walls: insights into the governing mechanisms. Water, Vol. 10, No. 4, 527, 2018.

[8] K. Perini, P. Rosasco. Cost-benefit analysis for green facades and living wall systems. Building and Environment, Vol.70, 110-121, 2013.

[9] M. Manso, J. Castro-Gomes. Green wall systems: A review of their characteristics. Renewable and Sustainable Energy Reviews, Vol. 41, 863-871, 2015.

[10] M. Weinmaster. Are green walls as "green” as they look? An introduction to the various technologies and ecological benefits of green walls. Journal of Green Building, Vol. 4, No. 4, 3-18, 2009.

[11] Q. Chen, B. Li, X. Liu. An experimental evaluation of the living wall system in hot and humid climate. Energy and buildings, Vol. 61, 298-307, 2013.

[12] U. Mazzali, F. Peron, M. Scarpa. Thermo-physical performances of living walls via field measurements and numerical analysis. WIT Transactions on Ecology and the Environment, Vol. 165, 251-259, 2012.

[13] R. Giordano, E. Montacchini, S. Tedesco, A. Perone, Living wall systems: a technical standard proposal. Energy Procedia, Vol. 111, 298-307, 2017.

[14] K. Perini, M. Ottelé. Designing green façades and living wall systems for sustainable constructions. International Journal of Design and Nature and Ecodynamics, 9(1), 31-46, 2014.

[15] Green Walls in High Rise Buildings -Types, Features and Benefits The constructor civil engineering home, Online available from https://theconstructor.org/building/green-wal ls-types-benefits-features/16625/

[16] C. Eves, S. Kippes. Public awareness of green and energy efficient residential property, Property Management, 2010.

[17] V. Oquendo-Di Cosola, F. Olivieri, L. Ruiz-García, \& J. Bacenetti. An environmental Life Cycle Assessment of Living Wall Systems. Journal of environmental management, 254, 109743, 2020.

[18] F. Abass, L.H. Ismail, I. A. Wahab, \& A. A. Elgadi. A Review of Green Roof: Definition, History, Evolution and Functions. In IOP Conference Series: Materials Science and Engineering (Vol. 713, No. 1). IOP Publishing, 2020. 